\title{
Granular cell tumor: a rare tumor of the ulnar nerve
} Case report

\author{
GaVIN A. DaVIS, M.B.B.S., F.R.A.C.S. \\ Department of Neurosurgery, Cabrini Hospital, Victoria, Australia
}

\begin{abstract}
$\checkmark$ Granular cell tumors of the ulnar nerve are extremely rare, with only two cases previously reported in the English literature. The author presents a case of granular cell tumor of the ulnar nerve, in which the tumor was resected and the nerve was repaired with a nerve graft. The histopathological characteristics, imaging findings, and clinical data regarding these tumors are reviewed, and based on all the available evidence, a new treatment paradigm is proposed, which differs from that used in the earlier reported cases and takes into account the reported rate of tumor recurrence after incomplete resection.
\end{abstract}

KEY WORDS - granular cell tumor - nerve tumor - peripheral nerve $\bullet$ ulnar nerve

B ENIGN GRANULAR CELL TUMORS are uncommon tumors that most frequently involve skin and subcutaneous tissue. Their involvement in major nerves is exceptionally rare, and only two cases involving the ulnar nerve have been identified in the English literature. ${ }^{2,9}$ This report adds a new case of granular cell tumor involving the ulnar nerve and reviews the previously published cases in light of this most recent one. A treatment paradigm for managing these tumors is presented.

\section{Case Report}

History and Presentation. This 36-year-old right-handed woman presented with a 1-year history of pain in the right hand. The pain was associated with some impairment of movement of the fifth digit of that hand and a tendency for the fourth and fifth digits to lock in certain positions. There was associated cramping of the hand at night with pain involving the medial aspect of the forearm, palm, and fifth digit. In the 6 months prior to presentation, the patient had noticed gradual wasting of the medial aspect of the hand, as well as a tender lump over the medial aspect of the right wrist. Her medical history was otherwise unremarkable, as was her family history.

Examination. Physical examination of the right upper limb revealed severe wasting of the hypothenar eminence and first dorsal interosseous muscle. The muscles inner-

\footnotetext{
Abbreviations used in this paper: LSUMC = Louisiana State University Medical Center; MR = magnetic resonance; PAS = periodic acid-Schiff.
}

vated by the proximal ulnar nerve (the flexor carpi ulnaris and flexor digitorum profundus) were normal. Strength in the intrinsic hand muscles innervated by the ulnar nerve was LSUMC Grade 0, with the exception of the ulnar nerve-innervated lumbrical muscles, in which it was Grade 2. Sensory examination revealed reduced sensation in the ulnar distribution, but sensory localization was still present. There was exquisite tenderness along the distal aspect of the forearm proximal to the Guyon canal.

A radiographic examination of the wrist had been performed previously, with normal results. An ultrasonographic examination of the wrist revealed a fusiform swelling at the level of the ulnar nerve for a distance of 42 $\mathrm{mm}$. The swelling extended over the distal ulna to the distal ulnar styloid process. An MR imaging study of the right forearm revealed a $4.5-\mathrm{cm}$-diameter mass, which showed uniform enhancement after administration of gadolinium and which arose from the ulnar nerve (Fig. 1).

Operation. The ulnar nerve was exposed in the distal right forearm. The $4.5-\mathrm{cm}$ tumor was identified within the nerve, and then an interfascicular neurolysis was performed (Fig. 2). This procedure allowed three normal fascicles to be dissected off the tumor and preserved. All the remaining ulnar nerve fascicles were intimately involved in the tumor itself and could not be dissected off it. Therefore, an en bloc resection was performed, and the involved nerve fascicles were resected together with the tumor. The resulting defect was repaired with a 5-cm nerve graft harvested from the medial cutaneous nerve of the forearm.

Histopathological Findings. Macroscopic examination of the resected tumor revealed a rubbery light gray appearance. Microscopic examination showed expansion of the 

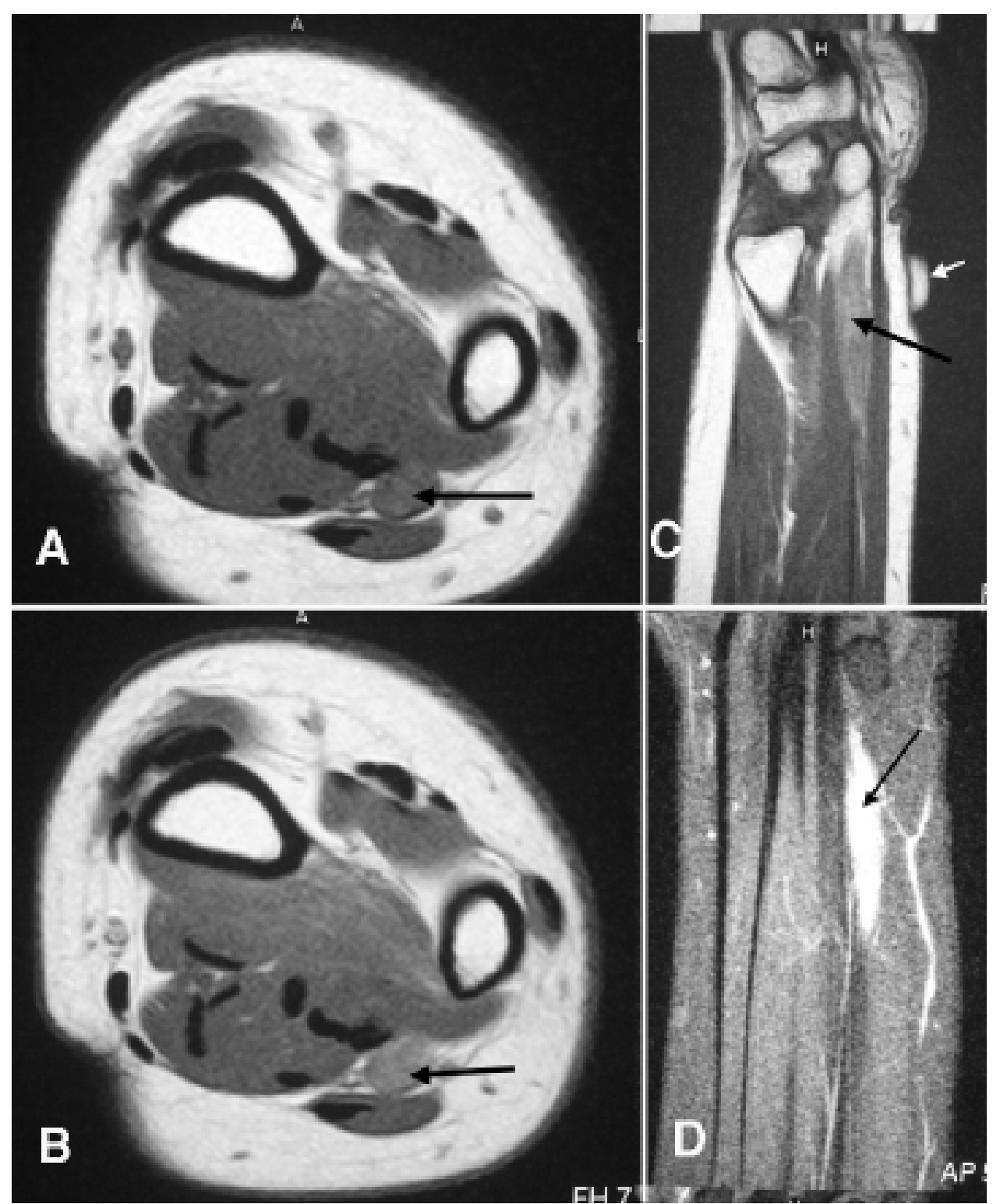

FIG. 1. Magnetic resonance images. A and B: Axial T1-weighted images, with (B) and without (A) contrast enhancement, demonstrating the tumor mass in the ulnar aspect of the forearm (arrow) C: Sagittal T1-weighted contrast-enhanced image demonstrating a radioopaque skin marker (white arrow) overlying the tumor (black arrow) D: Coronal short tau inversion recovery, contrast-enhanced image demonstrating the tumor mass in the ulnar aspect of the forearm (arrow).

nerve trunk and fascicles by cells that contained small irregular nucleoli and abundant eosinophilic granular cytoplasm. The tumor cells stained positively with PAS stain and antibodies to S100 protein (Fig. 3).

Postoperative Course. At the follow-up appointment 9 months after the surgical procedure, the patient demonstrated significant improvement in ulnar nerve function. She reported increased dexterity in picking up small objects with the right hand as well as improved sensory function. Motor examination revealed finger abduction to LSUMC Grade 2/5 (antigravity). By 12 months postoperatively, the patient's abduction function had improved to Grade 3/5 (against mild resistance), although she still had not regained adduction function.

\section{Discussion}

The term "granular cell tumor" refers to an uncommon tumor that has previously been known as granular cell myoblastoma, granular cell schwannoma, granular cell neurofibroma, granular neurogenic tumor, myoblastenmyome, and even the Abrikossoff tumor, following Abrikossoff's original description of it in 1926. ${ }^{1,3,7}$ Although the tumor was previously thought to be of myogenic origin, it is now thought to be of Schwann cell origin, and therefore the term "myoblastoma" is no longer valid. 3,6,8

Granular cell tumors are commonly located in the skin and subcutaneous tissue, and one quarter of all granular cell tumors are located in the tongue. The other common site for granular cell tumors is the breast. Less common 

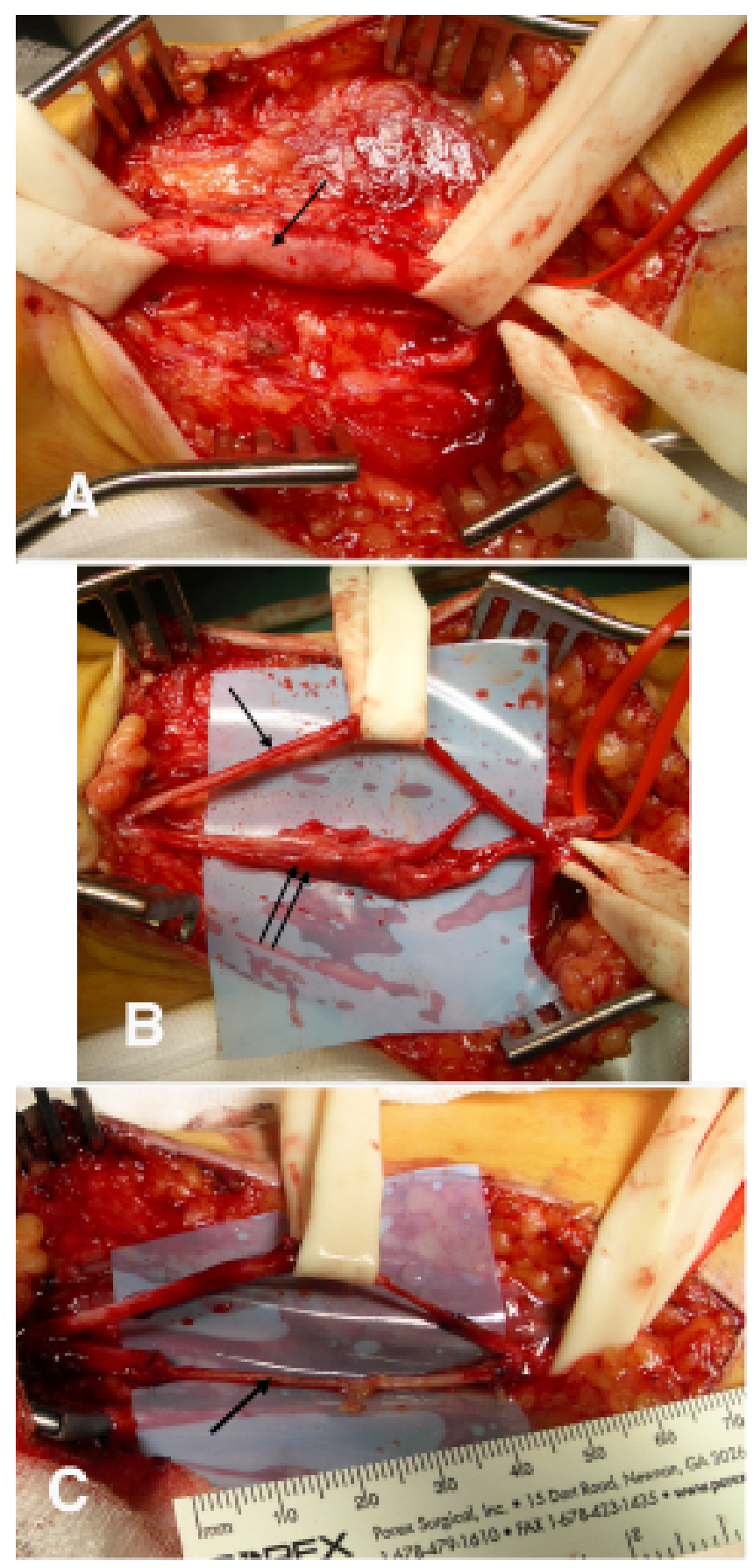

FIG. 2. Intraoperative photographs. A: The tumor mass (arrow) in the ulnar nerve. B: The ulnar nerve (single arrow) and tumor mass (double arrow) after interfascicular neurolysis. $\mathrm{C}$ : The ulnar nerve following tumor resection and split repair with nerve graft (arrow).

sites include the respiratory tract and the gastrointestinal tract. Despite the not uncommon association of granular cell tumors with small nerves in or around the tumors, it is exceptionally rare for a granular cell tumor to be found within a large named nerve in the upper or lower limb.

On pathological examination, granular cell tumors are usually solitary nodular lesions less than $3 \mathrm{~cm}$ in diameter

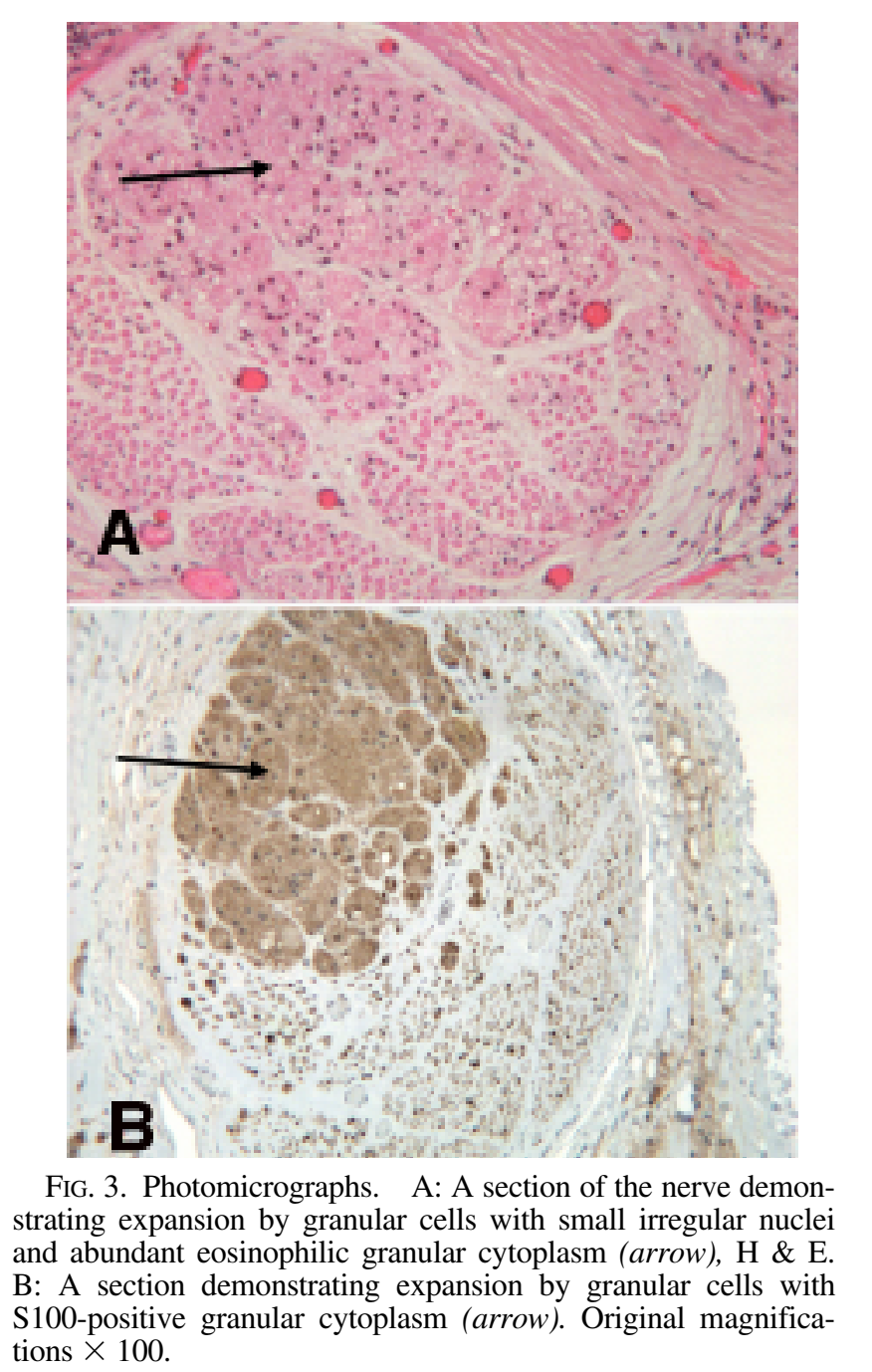

and appear gray-white to yellow in cross-section. Histologically, they are composed of cells of abundant eosinophilic granular cytoplasm. The granular appearance is due to the high content of lysosomes. The cytoplasmic granules are usually PAS-positive and stain positively for S100 protein. The results of other immunohistochemical studies can be positive in granular cell tumors, including testing for CD68, neuron-specific enolase, vimentin, and Leu-7. The concept that granular cell tumors are of peripheral nerve origin is supported by varying degrees of granular transformation of recognizable Schwann cells, a distinct basement membrane often surrounding granular cell clusters, the occasional presence of long-spacing collagen, and the presence among tumor cells of arrays of neuritic processes. ${ }^{4,6}$

As previously mentioned, the occurrence of granular cell tumors within named peripheral nerves is exceptionally rare, and only two previous cases of ulnar nerve involvement have been reported in the literature. ${ }^{2,9}$ Table 1 summarizes these cases in addition to the current case. The demographic data pertaining to the patients show an age range from 16 to 51 years and sex distribution of two men and one woman. Two tumors were on the left side and one on the right side, and the tumor size varied be- 
TABLE 1

Repored cases of winar nerve granular cell umors*

\begin{tabular}{|c|c|c|c|c|c|c|c|c|c|}
\hline $\begin{array}{l}\text { Authors } \\
\text { \& Yr }\end{array}$ & $\begin{array}{l}\text { Age \& Ses } \\
\text { of Putient }\end{array}$ & Location & $\begin{array}{l}\text { Tumor Di- } \\
\text { ameter (cm) }\end{array}$ & Presenting Sx & $\begin{array}{l}\text { Duration } \\
\text { of } \mathrm{Sx} \text { (mos) }\end{array}$ & $\begin{array}{l}\text { Imagitre ln- } \\
\text { vestigations }\end{array}$ & Treatment & $\begin{array}{l}\text { Histol } \\
\text { Findlings }\end{array}$ & $\begin{array}{l}\text { Follkw-Up } \\
\text { \& Results }\end{array}$ \\
\hline $\begin{array}{l}\text { Yasutomi } \\
\text { et al.. } \\
1999\end{array}$ & 51. M & $\begin{array}{l}\text { it side, } 3 \mathrm{~cm} \\
\text { proximal to } \\
\text { wrist crease }\end{array}$ & 1.5 & $\begin{array}{l}\text { numbiness, weakness, } \\
\text { atrophy. Tinel + }\end{array}$ & 3 & $\begin{array}{l}\text { x-ray. } \\
\text { US }\end{array}$ & $\begin{array}{l}\text { resection } \\
\text { ("shelled } \\
\text { out") }\end{array}$ & $\begin{array}{l}\text { polygonal cells, } \\
\text { granular } \\
\text { cytoplasm, } \\
\text { small dense } \\
\text { nuclei. S100+ }\end{array}$ & $\begin{array}{l}2 \text { yrs: pain } \\
\text { resolved. } \\
\text { persistent } \\
\text { weakness }\end{array}$ \\
\hline $\begin{array}{l}\text { Dahlin } \\
\text { et al. } \\
2002\end{array}$ & $16, \mathrm{M}$ & $\begin{array}{l}\text { It side, "just } \\
\text { distal to ulnar } \\
\text { groove at clbov" }\end{array}$ & 3 & $\begin{array}{l}\text { numbess, } \\
\text { paresthesis, } \\
\text { Tinel }+ \text {, weakness }\end{array}$ & 12 & $\begin{array}{l}\text { x-ray, } \\
\text { MRI }\end{array}$ & bx only & $\begin{array}{l}\text { granular } \\
\text { ecsinophilic } \\
\text { cyloplasm, } \\
\text { small rounded, } \\
\text { nuclei, PAS + }\end{array}$ & $\begin{array}{l}\text { postop: incr } \\
\text { weakness } \\
2.5 \text { yrs: MRI } \\
\text { showed tumor } \\
\text { growth to } 4 \\
\mathrm{~cm} \text {; } 2 \text { nd bs } \\
\text { showed no cs } \\
\text { in histol find- } \\
\text { inges } 3.5 \text { yrs: } \\
\text { continue } \\
\text { to observe }\end{array}$ \\
\hline $\begin{array}{l}\text { present } \\
\text { report }\end{array}$ & $36 . \mathrm{F}$ & $\begin{array}{l}\text { rt side, level of } \\
\text { distal ulna, I cm } \\
\text { proximal to } \\
\text { wrist crcase }\end{array}$ & 4.5 & $\begin{array}{l}\text { bender lump, cramps, } \\
\text { progressively incr } \\
\text { pain, wasting. \& } \\
\text { weakness. }\end{array}$ & 12 & $\begin{array}{l}x \text {-ray. } \\
\text { US. } \\
\text { MRI }\end{array}$ & $\begin{array}{l}\text { neurolysis } \\
\text { (interfas- } \\
\text { cicular') w/ } \\
\text { tumor resec- } \\
\text { tion \& } 5-\mathrm{cm} \\
\text { nerve graft }\end{array}$ & $\begin{array}{l}\text { small nuckei, } \\
\text { exsinophilic } \\
\text { granular } \\
\text { cyloplasm, } \\
\text { PAS +. } \\
\text { S100+ }\end{array}$ & $\begin{array}{l}\text { I yr: functional } \\
\text { motor (esp } \\
\text { abductor digiti } \\
\text { minimi) } \\
\text { \& sensory } \\
\text { impr }\end{array}$ \\
\hline
\end{tabular}

" bs = biopsy ex = changes; esp = especially; histol - hissological; impr = improvement; incr = increased; sx = signs and symptoms; US = ultrusound.

tween 1.5 and $4.5 \mathrm{~cm}$ in maximum diameter. All patients presented with a combination of numbness, weakness, wasting, and/or positive Tinel sign. The duration of symptoms varied between 3 months and 1 year prior to treatment. The earliest reported case was investigated with radiography and ultrasonography, and clinicians treating the later two cases had the added advantage of MR imaging. The tumors demonstrated patchy to uniform enhancement on MR images.

It is interesting that the three tumors were managed differently. In the case reported by Yasutomi et al., the tumor could be "shelled out" from the ulnar nerve. ${ }^{9}$ In the case reported by Dahlin et al., the nerve was so intimately involved that the authors were unable to resect the tumor and performed a biopsy only. ${ }^{2}$ In the case reported in this paper, a similar finding of intermingling of tumor and nerve fibers was identified, but I elected to resect the tumor and repair the nerve gap with nerve graft. Comparing the results achieved with biopsy only ${ }^{2}$ and the current case, it is noted that, with biopsy only, the patient developed increasing weakness postoperatively. Subsequent examination and investigation revealed an increase in tumor size, and another biopsy procedure was performed 2 $1 / 2$ years after the initial procedure. In contrast, following resection and placement of a nerve graft, the patient in the current reported case demonstrated significant symptomatic improvement in sensory and motor function.

Granular cell tumors at other locations have been reported to recur at rates between 2 and $8 \%$ in cases in which resection margins were clear and at rates up to $50 \%$ after incomplete excision. ${ }^{6}$ In a report of 110 cases of granular cell tumors, it was observed that there was an $8 \%$ recurrence rate in the group of patients in whom one or more resection margins were involved by tumor as well as in the group of patients with clear resection margins, ${ }^{5}$ but these cases involved tumors of organs such as the skin, tongue, and breast and none occurred in major named peripheral nerves. The true recurrence rate in nerve granular cell tumors is unknown. To reduce the risk of recurrence, I believe that the most appropriate treatment for granular cell tumors of the ulnar nerve is complete macroscopic excision of the tumor and, when necessary, repair of the ulnar nerve with cable nerve grafts.

The differential diagnosis for these tumors includes neurofibroma and schwannoma. On clinical and imaging grounds, there are no distinguishing features to enable the peripheral nerve surgeon to differentiate the more common schwannoma and neurofibroma from the very rare granular cell tumor. It will therefore be highly unlikely that the peripheral nerve surgeon will anticipate the diagnosis of granular cell tumor in any individual case, and this may have a bearing on the surgical management. This relates to the high recurrence rate reported in granular cell tumors, although the long-term recurrence rate for cases involving the ulnar nerve is currently unknown. As reports of additional cases accumulate in the literature, we may be able to determine the true clinical and imaging recurrence rates and develop appropriate management guidelines accordingly. In the interim, however, I firmly believe that complete resection of these tumors, with nerve grafts as appropriate, is the treatment of choice.

\section{Conclusion}

Granular cell tumors are very rare tumors of Schwann cell origin that can involve the ulnar nerve, resulting in significant weakness, wasting, and numbness in the hand. Resection and nerve grafting can result in a good outcome in these patients, but the long-term recurrence rate is unknown. 


\section{Acknowledgments}

I thank Drs. William Downey, Warren McNaughton, and Peter Wallis, as well as the Cabrini pathology staff, for their assistance in producing the photomicrographs.

\section{References}

1. Abrikossoff A: Über Myome ausgehend von der quergestreiften willkürlichen Muskulatur. Virchows Arch (Pathol Anat) 260: 215-233, 1926

2. Dahlin LB, Lorentzen M, Besjakov J, Lundborg G: Granular cell tumor of the ulnar nerve in a young adult. Scand J Plastic Reconstr Surg Hand Surg 36:46-49, 2002

3. Fisher ER, Wechsler H: Granular cell myoblastoma-a misnomer. Electron microscopic and histochemical evidence concerning its Schwann cell derivation and nature (granular cell schwannoma). Cancer 15:936-954, 1962

4. Forthman CL, Blazar PE: Nerve tumors of the hand and upper extremity. Hand Clin 20:233-242, 2004

5. Lack EE, Worsham GF, Callihan MD, Crawford BE, Klap- penbach S, Rowden G, et al: Granular cell tumor: a clinicopathologic study of 110 patients. J Surg Oncol 13:301-316, 1980

6. Scheithauer BW, Woodruff JM, Erlandson RA: Tumors of the peripheral nervous system, in Rosai J, Sobin LH (eds): Atlas of Tumor Pathology. Third Series, Fascicle 24. Washington, DC: Armed Forces Institute of Pathology, 1999, pp 248-259

7. Silva-Lopez E, Wood DK: Granular cell myoblastoma. Curr Surg 40:202-206, 1983

8. Sobel HJ, Marquet E, Schwarz R: Is schwannoma related to granular cell myoblastoma? Arch Pathol 95:396-401, 1973

9. Yasutomi T, Koike H, Nakatsuchi Y: Granular cell tumor of the ulnar nerve. J Hand Surg [Br] 24:122-124, 1999

Manuscript submitted Februrary 15, 2007.

Accepted April 24, 2007.

Address reprint requests to: Gavin A. Davis, M.B.B.S., F.R.A.C.S., Suite 53-Neurosurgery, Cabrini Medical Centre, Malvern, Victoria 3144, Australia. email gadavis@ netspace.net.au. 